Journal of Social Sciences 7 (3): 380-385, 2011

ISSN 1549-3652

(C) 2011 Science Publications

\title{
Optimization of Rowing Specific Training by Studying the Stages Evaluation
}

\author{
Sanda Toma Urichianu and Potop Vladimir \\ Ecological University of Bucharest, Faculty of Physical Education and Sport, Romania
}

\begin{abstract}
Problem statement: We intended to analyze and systematize the most valuable ways through which is achieved the optimization in rowing training by the evaluation of control norms, trials and tests during some stages of the training plan. We consider that the sports performances can become better and better thanks to a continuous improvement of the working methodology during the main periods of training. Approach: The study was conducted over a period of 10 months (December 1, 2009-September 1, 2010) within the Sports Clubs, Juniors Department, men, of Falticeni and Iasi and it was made during the pre-competitive and competitive training period. The subjects of our research represent a group of 24 athletes from the two clubs: CS Falticeni and CS Iasi, out of which only 9 subjects have been able to obtained significant results. The study emphasizes the performances achieved during the control tests on ergometer rowing machines and on water $(6000$ and $2000 \mathrm{~m}$ events). Results: The study results confirmed that there is a significant relationship of the control tests results, erg and the competitive performance. The athletes' performance is determined by the level of physical training specific to the rowing. Conclusions: To further enhance the performances, one should not neglect the study of any side which could help coaches and methods specialists in their work with the athletes.
\end{abstract}

Key words: Rowing, specific training, evaluation, valuable ways, moral-volitional traits, major competitions, hypotheses of the study, strength circuit

\section{INTRODUCTION}

Because of the type of demands imposed on the athletes, the rowing claims from the persons practicing it a series of well-shaped physical and mental skills (Colibaba and Bota, 2005) and constitutes an admirable strengthening way with benefic influences on the body due to the favorable conditions of practice: Water, open air, sunlight, a continuous variety of views and impressions.

In addition to the applicative motor skills, the rowing develops precious motor and moral- volitional traits of the persons who practice it. The rower becomes stronger, learns to win, to fight fatigue and to be resolute in his actions.

The sports performances in rowing have reached a high value level at the present moment. Among the sports performances development trends we mention the use of new means and methods and the training methodology improvement as well. An optimal balance reached between the results of both non-specific and specific control trials, tests (Tu and Koh, 2010) and norms on ergo and the results on boats can contribute to the achievement of high sports performances in the competitions to come.

We consider the ability to train and to compete as a complex factor in achieving performance in rowing. In order to train athletes for rowing at juniors' level, a thorough examination of the rowing requirements should be made, so that certain traits can be identified in the young athlete.

The physical work capacity is a highly important factor in rowing. Physical strength and motivation can be improved at each individual up to a certain limit. Large testing actions are needed to form a group of athletes with potential for practicing high performance rowing, because it is likely that only a small percentage among the tested persons meet the requirements imposed.

We cannot contest the validity and value of the concepts, theories and technologies issued by wellknown theorists in sports training field, particularly in rowing, especially since the performance (Janmanee and Muttamara, 2010) has been continuously progressing. Therefore, there is always the possibility of renewal, modernization of sports selection process which may also lead to achieving superior performances in major competitions. 
Purpose of the study: This study aims at finding the main directions through each is achieved the optimization of the rowing training by means of the control norms, tests and trials evaluation in some stages of the training plan.

The actions and procedures undertaken in this study are intended to provide a quantifiable material about the training level of the young rowers co-opted to practice performance rowing.

Hypotheses of the study: It is hypothetically considered that between the result of the control norms, trials and tests and the result of the competitions in the very next stage there is a positive and significant correlation amended by the time period between recordings, the individual behavior of the rower in shell (single or crew), the emotions or other mental factors or even the materials quality.

One considers that the rate of progress in the competition results at the classic control trials (on-water rowing and indoors rowing) is significant for the specific training process.

Study organization and conduct: The study was conducted over a period of 10 months (December 1 , 2009-September 1, 2010) in the Sports Clubs of Falticeni and Iaşi, juniors' men rowing department.

The tests were performed throughout a precompetitive and competitive training period.

The subjects of our research are a group of 24 athletes belonging to the two clubs: CS Falticeni and CS Iasi, out of which only 9 subjects have recorded promising results.

The athletes are juniors (17-18 years old) with an intensive training up to 3 years long; they train under a training camp program: Monday through Friday they make 2 rowing sessions (outdoors or indoors) and a strength training session (circuit) that alternates with a running one. On Saturday the athletes have a rowing and a running training session (30 $\mathrm{min})$ and on Sunday they have a rowing training session.

\section{MATERIALS AND METHODS}

The study was made starting from the training programs by land (strength circuit, running, ergs) and the on-water technique in sculling crews (1XM) and sweep-oar rowing crews (2M-), monitoring statistically the parameters evolution in the control trials and on the test lanes.

The statistical processing was made in Word and "KyPlot" programs.

\section{RESULTS}

The testing was done on a group of 24 athletes at the beginning of the first training stage (December 2009). Table 1 and Fig. 1 shows a summary of the rankings obtained by the subjects in the ten events within test no. 1 (3rd-12th columns); in the 13th column we find the mean of the rankings got by the subjects in this test.

In Table 2 and Fig. 2 is shown the rankings evolution in the 10 trials of $\mathrm{T} 2$ test. The last column shows the average of the 10 rankings of the subjects. The T2 test took place in the 2nd stage (May 2010).

We can notice in Fig. 3 the evolution of T1 mean related to $\mathrm{T} 2$ mean, the general mean of the study subjects and the progresses recorded by some athletes in the control trials.

In Table 3 is shown the overall average rankings obtained by the subjects at both T1 and T2 tests.

In Table 4 is shown the results of correlation between test 1 and test 2

\section{DISCUSSION}

The evolution of the effort parameters (Sanong et al., 2010) in the control trials by land and on water applied in the physical and technical training programs of junior rowers during the study was exemplified along the off-water and on-water training period in 5 trials; these ones also included the participation of 9 athletes in the Romanian Cup, the $6000 \mathrm{~m}$ on-water middle-distance race and in the Individual National Championship - 2000 m.

Table 1: Subjects' ranking at each trial of T1 testing and their mean

\begin{tabular}{|c|c|c|c|c|c|c|c|c|c|c|c|}
\hline S.p. & $\begin{array}{l}\text { Run } \\
1200\end{array}$ & $\begin{array}{l}\text { Ergo } \\
500 \mathrm{~m}\end{array}$ & $\begin{array}{l}\text { Row } \\
90 "\end{array}$ & Hanging & $\begin{array}{l}\text { Genuf } \\
90 "\end{array}$ & $\begin{array}{l}\text { Long } \\
\text { jump }\end{array}$ & $\begin{array}{l}\text { Standing } \\
\text { jump }\end{array}$ & Crunches & $\begin{array}{l}\text { Bench } \\
\text { back }\end{array}$ & $\begin{array}{l}\text { Row } \\
30^{\prime}\end{array}$ & Mean \\
\hline Mean & 12.50 & 12.50 & 125.00 & 12.50 & 12.50 & 12.50 & 12.50 & 12.50 & 12.50 & 12.50 & 12.5 \\
\hline S.E.M. & 1.44 & 1.44 & 1.44 & 1.44 & 1.44 & 1.44 & 1.44 & 1.44 & 1.44 & 1.44 & 0.73 \\
\hline S.D. & 7.07 & 7.07 & 7.07 & 7.07 & 7.07 & 7.07 & 7.07 & 7.07 & 7.07 & 7.07 & 3.59 \\
\hline Coeff. Var. & 56.60 & 56.60 & 56.60 & 56.60 & 56.60 & 56.60 & 56.60 & 56.60 & 56.60 & 56.60 & 28.7 \\
\hline
\end{tabular}


J. Social Sci., 7 (3): 380-385, 2011

\begin{tabular}{|c|c|c|c|c|c|c|c|c|c|c|c|}
\hline S.p. & $\begin{array}{l}\text { Run } \\
1200\end{array}$ & $\begin{array}{l}\text { Ergo } \\
500\end{array}$ & $\begin{array}{l}\text { Row } \\
90^{\prime \prime}\end{array}$ & Hanging & $\begin{array}{l}\text { Genuf } \\
90^{\prime \prime}\end{array}$ & $\begin{array}{l}\text { Long } \\
\text { jump }\end{array}$ & $\begin{array}{l}\text { Standing } \\
\text { jump }\end{array}$ & Crunch & $\begin{array}{l}\text { Bench } \\
\text { back }\end{array}$ & $\begin{array}{l}\text { Row } \\
30^{\prime} \\
\end{array}$ & Mean \\
\hline Mean & 12.50 & 12.50 & 12.50 & 12.50 & 12.50 & 12.50 & 12.50 & 12.50 & 12.50 & 12.5 & 12.50 \\
\hline S.E.M. & 1.44 & 1.44 & 1.44 & 1.44 & 1.44 & 1.44 & 1.44 & 1.44 & 1.44 & 1.44 & 0.91 \\
\hline S.D. & 7.07 & 7.07 & 7.07 & 7.07 & 7.07 & 7.07 & 7.07 & 7.07 & 7.07 & 7.07 & 4.44 \\
\hline Coef. Var. & 56.60 & 56.60 & 56.60 & 56.60 & 56.60 & 56.60 & 56.60 & 56.60 & 56.60 & 56.6 & 35.50 \\
\hline
\end{tabular}

\begin{tabular}{lllll}
\multicolumn{1}{l}{ Table 3: Overall average rankings obtained by the subjects at both T1 and T2 tests } \\
\hline & Mean & Mean & & \\
Full name & T1 & T2 & Total & General mean \\
\hline $\begin{array}{l}\text { Multiple correlations } \\
\text { Parametric test }\end{array}$ & Group 1 & Group 2 & Group 3 & Group 4 \\
Group 1 & 0 NS $(\mathrm{P}>0.05)$ & $8.51 \mathrm{P}<=0.001$ & $1.209 \mathrm{NS}(\mathrm{P}>0.05)$ & \\
Group 2 & 1 & & $8.51 \mathrm{P}<=0.001$ & $1.209 \mathrm{NS}(\mathrm{P}>0.05)$ \\
Group 3 & 1.607 & 1.607 & & $-8.51 \mathrm{P}<=0.001$ \\
Group 4 & 1 & 1 & 1.61 & \\
\hline
\end{tabular}

\begin{tabular}{|c|c|c|c|c|c|c|c|c|c|c|c|}
\hline & $\begin{array}{l}\text { Run } \\
1200 \\
\end{array}$ & $\begin{array}{l}\text { Ergo } \\
500 \mathrm{~m}\end{array}$ & Row 90" & Hanging & $\begin{array}{l}\text { Genuf } \\
90 "\end{array}$ & $\begin{array}{l}\text { Long } \\
\text { jump }\end{array}$ & $\begin{array}{l}\text { Stand } \\
\text { jump }\end{array}$ & Crunch & $\begin{array}{l}\text { Bench } \\
\text { back }\end{array}$ & $\begin{array}{l}\text { Row } \\
30^{\prime} \\
\end{array}$ & Mean \\
\hline r-Coeff. & & & & & & & & & & & \\
\hline \multirow[t]{3}{*}{ Correlation } & 0.770 & 0.360 & 0.76 & 0.460 & 0.60 & 0.81 & 0.460 & 0.72 & 0.460 & 0.72 & 0.750 \\
\hline & & & 1.81 & 5.570 & 2.44 & 3.52 & 2.470 & 4.90 & 2.470 & 4.90 & 5.320 \\
\hline & 5.829 & $(>05)$ & & $\mathrm{p}<0.001$ & $\mathrm{p}<0.05$ & $\mathrm{p}<0.01$ & $\mathrm{p}<0.001$ & $\mathrm{P}<0.05$ & $\mathrm{p}<0.001$ & $\mathrm{p}<0.05$ & $\mathrm{p}<0.001$ \\
\hline
\end{tabular}

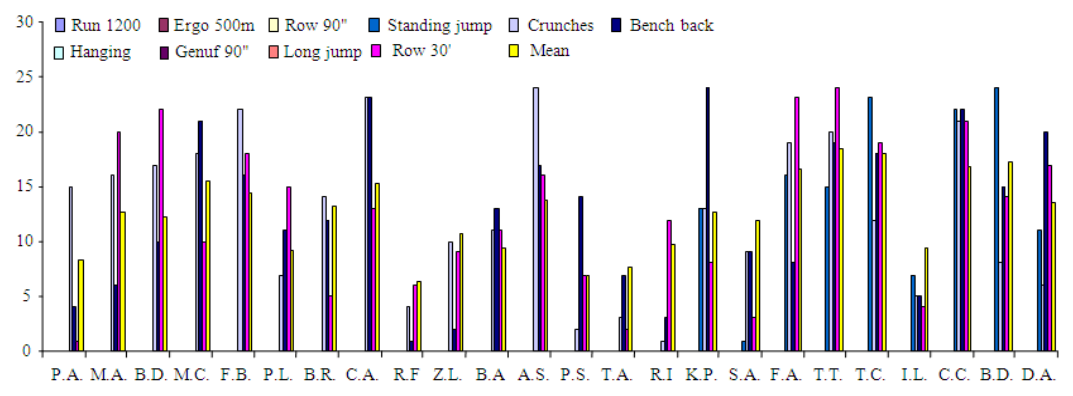

Fig. 1: Subjects' ranking at each trial of T1 testing

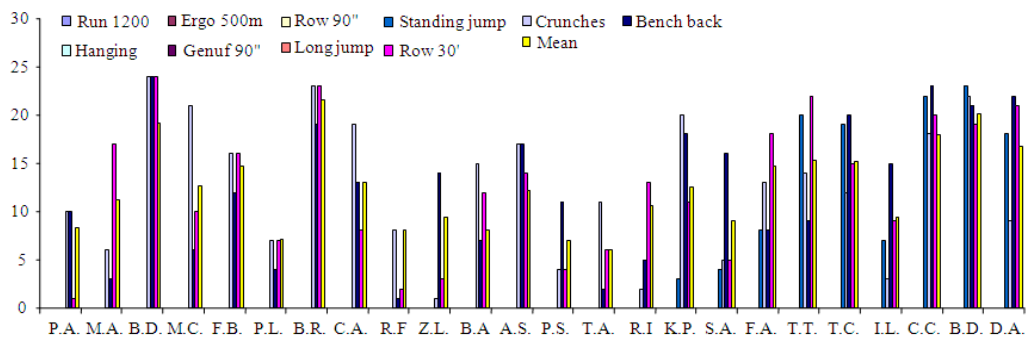

Fig. 2: Subjects' ranking at each trial of T2 testing 


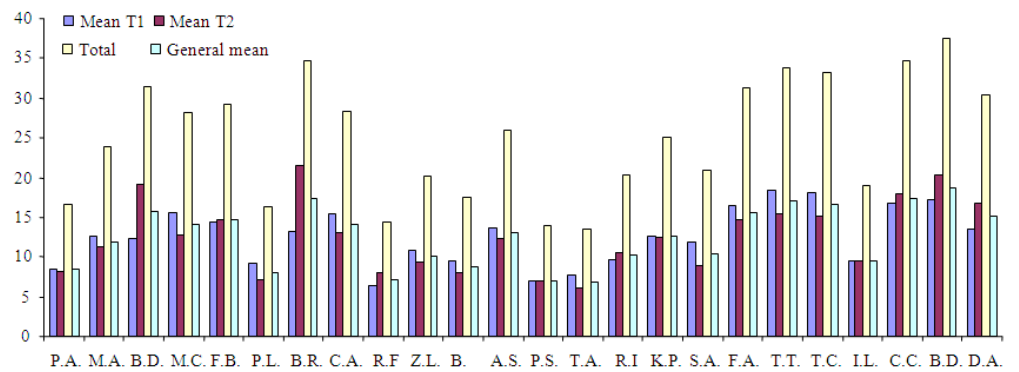

Fig. 3: Overall average rankings obtained by the subjects at both $\mathrm{T} 1$ and $\mathrm{T} 2$ tests

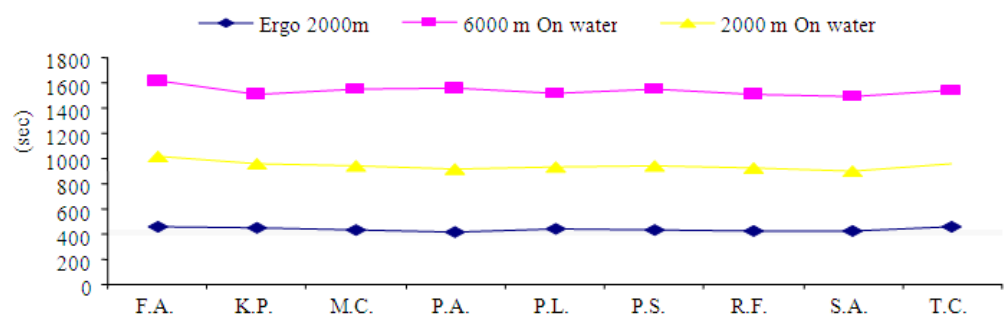

Fig. 4: Results of control trials, performances in competition

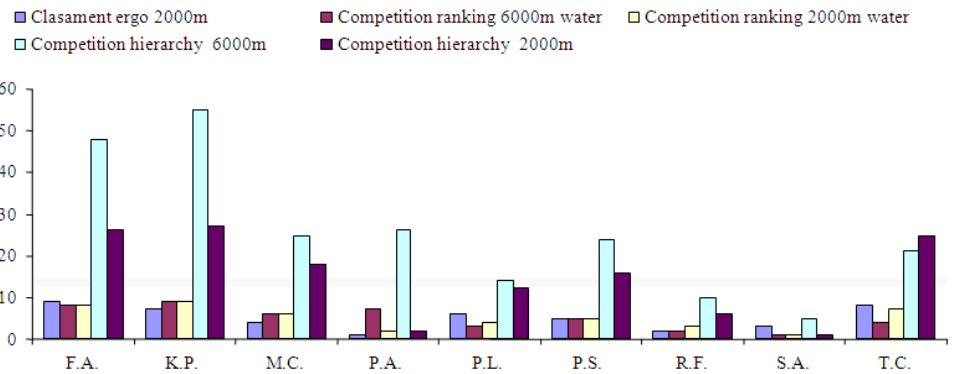

Fig. 5: Competition ranking and study group ranking

Comment [U1]: Not discuss ok

\begin{tabular}{llrll}
\multicolumn{5}{l}{ Table 5: Ergs control norms on 2000m, January 2010 } \\
\hline No. & $\begin{array}{l}\text { Full name } \\
\text { Ranking }\end{array}$ & Ergo 2000m \\
\hline 1 & F.A. & $7: 38.1$ & 458.10 & 9 \\
2 & K.P. & $7: 33.6$ & 453.60 & 7 \\
3 & M.C. & $7: 11.1$ & 431.10 & 4 \\
4 & P.A. & $7: 00.0$ & 420.00 & 1 \\
5 & P.L. & $7: 19.0$ & 439.0 & 6 \\
6 & P.S. & $7: 17.0$ & 437.00 & 5 \\
7 & R.F. & $7: 01.2$ & 421.20 & 2 \\
8 & S.A. & $7: 02.0$ & 422.00 & 3 \\
9 & T.C. & $7: 34.2$ & 454.20 & 8 \\
Mean & \multicolumn{5}{c}{437.35 .0} & 5.00 & \\
S.E.M. & 5.02 .0 & 0.91 & \\
S.D. & \multicolumn{5}{c}{15.07 .0} & 2.73 & \\
Coeff. Var. & \multicolumn{5}{c}{54.70} \\
\hline
\end{tabular}

To a great extent, the results of the control norms are statistically correlated in a significant (Momani et $a l ., 2010)$ way in longitudinal plane $(\mathrm{r}=0.75)$, proving the fact that the rate of progress is a key indicator of the training process (Table 4).

We mention that from the end of the first step of the initial stage up to the intermediate one of the selection held 6 months after, 9 subjects have been maintained in centralized training (Naglaa et al., 2010) and have been submitted to a somaticfunctional assessment.

In January 2010, the athletes ranked on the first 9 383 places at the control trials were tested at the ergo 
meter rowing machine on a $2000 \mathrm{~m}$ distance. Table 5 shows the results obtained.

In April 2010 the 9 athletes participated in competition, obtaining the results in Table 6 and Fig. 4 and 5.

In connection with the results got in the 2 nd stage competitions, some significant statistical correlations (Attarzadeh and Ow, 2010) can be noticed, such as the correlation between ergs trials and on-water events (2000 m distance), a possible causal correlation because the correlation coefficient is much higher than the critical one; the same thing can be observed as for the correlation between the on-water competitions (6000 $\mathrm{m}$ distance) and the initial selection norms (Table 7).

Therefore we have the confirmation of the hypothesis that the results of the control trials in 1st stage and those during 2nd stage should not be linked because the training (Qicai et al., 2009) is logically designed in several non-compensative steps and the substitution is inappropriate.

We are tempted to interpret some of the qualitative data of the training process without, however, attributing them a certain predictive power. So, at each trial separately, we have noticed significant oscillations, probably because of the rowing short stage of the subjects or of the influences exerted by the mental, environmental or even technical-tactical factors. The objectivity of the trial on ergo meter rowing machines on a $2000 \mathrm{~m}$ distance seems to be questionable (the correlation coefficient of the two tests, in terms of rowing technique and of stereotypical skills that require a longer experience).

\begin{tabular}{|c|c|c|c|c|}
\hline \multirow[b]{2}{*}{ Full name } & \multicolumn{2}{|c|}{ Final time } & \multirow{2}{*}{$\begin{array}{l}\text { Competition } \\
\text { ranking }\end{array}$} & \multirow{2}{*}{ Group } \\
\hline & Min & Sec. & & \\
\hline Mean & & 942.05 & 13.50 & 4.75 \\
\hline S.E.M. & & 12.70 & 3.56 & 0.99 \\
\hline S.D. & & 35.90 & 10.08 & 2.82 \\
\hline Coef. Var. & & 3.81 & 74.70 & 59.20 \\
\hline
\end{tabular}

Table 7: Individual National Championship, August 2010, $2000 \mathrm{~m}$ on-water

\begin{tabular}{|c|c|c|c|c|c|}
\hline \multirow[b]{2}{*}{ No, } & \multirow[b]{2}{*}{$\begin{array}{l}\text { Full name } \\
\text { ranking }\end{array}$} & \multicolumn{2}{|l|}{ Final time } & \multirow[b]{2}{*}{$\begin{array}{l}\text { Competition } \\
\text { ranking }\end{array}$} & \multirow[b]{2}{*}{ Group } \\
\hline & & $\begin{array}{l}\text { Min, sec, } \\
\text { mlsec. }\end{array}$ & $\begin{array}{l}\text { Transf. } \\
\text { Sec. }\end{array}$ & & \\
\hline Mean & & $25: 39,18$ & 1539.18 & 25.33 & 5.00 \\
\hline S.E.M. & & & 11.92 & 5.51 & 0.91 \\
\hline S.D. & & & 35.77 & 16.55 & 2.73 \\
\hline Coef. Var. & & & 2.32 & 65.30 & 54.70 \\
\hline
\end{tabular}

\section{CONCLUSION}

The study assumption that there is a positive and significant correlation between the result of the control norms, trials and tests and the result of the immediately next stage competitions has been confirmed by the statistical analysis of the tests results.

The interpretation of the practical application results shows also that the training by stages is a dynamic process, constantly improving and adapting to the actual conditions. For example, we refer to the fact that attracting the young people to practice performance rowing is more and more difficult (only 9 athletes out of a group of 24 have proved significant performances), because of the conjectural temptations, the limited possibilities to make attractive and compensative the special effort until the targets intended are reached.

After the interpretation of the tests results we are tempted to assess the athletes' possible performances in the competitions to come. Although we have noticed oscillations at each trial separately, probably caused by the subjects' short stage of rowing or by the influences of the mental, environmental or even technical-tactical factor, visible progresses are remarked at the end of the general and specific training stage.

To further enhance the performances (Pantouvakis et al., 2010) one should not neglect the study of any side which could help coaches and methods specialists in their work with the athletes.

\section{REFERENCES}

Attarzadeh, I. and S.H. Ow, 2010. A novel algorithmic cost estimation model based on soft computing technique. J. Comput. Sci., 6: 117-125. ISSN: 1549-3636

Colibaba, E.D. and I. Bota, 2005. Theory and methodology of sports training in sports. 4th Edn., Human Kinetics, ISBN-10: 0880118512, pp: 424.

Janmanee, P. and A. Muttamara, 2010. Performance of difference electrode materials in electrical discharge machining of tungsten carbide. Energy Res. J., 1: 87-90. ISSN: 1949-0151

Momani, G.F., M.A. Alsharayri and M.M. Dandan, 2010. Impact of firm's characteristics on determining the financial structure on the insurance sector firms in Jordan. J. Soc. Sci., 6: 282-286. ISSN: 1549-3652

Naglaa, F.A. et al., 2010. Effect of exercise training on adiponectin receptor expression and insulin resistance in mice fed a high fat diet. Am. J. Biochem. Biotechnol., 6: 77-83. ISSN: 1553-3468 
Pantouvakis, A.M., C.I. Chlomoudis and A.G. Dimas, 2010. Marketing strategies in port industry: An exploratory study and a research agenda. Am. J. Econ. Bus. Admin., 2: 65-66. ISSN: 1945-5488

Qicai, L., Z. Kai, Z. Zehao, F. Lengxi and O. Qishui $e t$ $a l ., 2009$. The use of artificial neural networks in analysis cationic trypsinogen gene and hepatitis $b$ surface antigen. Am. J. Immunol., 5: 50-55. ISSN: 1553-619X
Sanong, A., N. Theera-Umpon, W. Kittichai and A. Sansanee, 2010. Moisture content prediction of dried longan aril from dielectric constant using multilayer perceptrons and support vector regression. Am. J. Applied Sci., 7: 1388-1389. ISSN: $1546-9239$

Tu, C. and W.Y. Koh, 2010. Using bioequivalence approach to assess toxicity effect of herbal products, tyrel and rumbion. Am. J. Pharmacol. Toxicol., 5: 109-111. ISSN: 1557-4962 